\title{
Study of large shareholders' behavior after non-tradable shares reform: A perspective of related party transactions
}

\author{
Hongbo Zhang ${ }^{1}$, Qing Xia ${ }^{2}$ \\ ${ }^{1}$ Wuhan University (China), ${ }^{2}$ Military Economics Academy (China) \\ zhbbank@.gmail.com,casa2005@sina.com
}

Received: March 2013

Accepted: June 2013

\section{Abstract:}

Purpose The most important feature of modern corporations is the separation of investors' ownership and managers' control. With the development of modern corporate system, principal-agent problem has been replaced by the agent problem between large shareholders and small shareholders gradually. The reform of rights and interests started from April 30, 2005 is aimed to realize the convergence of the interests of shareholders, improve the corporation management and reduce the controllers' private benefits. However, with the strengthening of market mechanisms large shareholders possibly grab private benefits by means of multiple controls of corporation and the secondary market. According to statistics, by the end of 2012, more than $95 \%$ of the original state-owned listed company completed the reform of rights and interests. With the banning of non-tradable shares has been relieved, China capital market starts to embrace the new era of full share circulation, which could further aggravate big shareholders encroaching upon small ones. Therefore, the purpose of this paper is to provide an approach to study the large shareholders behavior after the Non-tradable Share Reform especially from the view of Related Party Transactions.

Design/mathoddogy/approadr This paper explores the behavior choice of large shareholders in the related party transactions which occur between the large shareholders and listed companies by using the data of shares from 2007 to 2010. Based on the classical research paradigm (that is, LLSV), this article analysis controlling shareholders' propping and tunneling behaviors aiming to make sure their impacts to the medium and small shareholders in theory. 
Findings: We get the following findings: After our capital market entering the era of full circulation, we find that the relationship between the ratio of controlling shareholders and the related party transactions present (RPTs) an inverted "U" shape curve, which means that it exits a typical "Grab-synergy" effect. We should take different measures to the transactions occurred between the large shareholders and listed companies according to the property nature of the large shareholders. State-owned shareholders choose to realize their private benefits by means of RPTs, while the non-state-owned shareholders conduct RPTs with an expectation of reducing costs.

Practical implications: Since Guo Shuqing, the Chairman of China Securities Regulatory Commission, took office, he has taken a lot measures to curb the related party transactions harshly. Under this circumstance, it is just the right time to have a research on large shareholders' behavior. It has important significance both in theory and practice.

Originality/value Considering the Chinese special national conditions, this paper added lots of comprehensive facts to study large shareholders' behavior including the rate of the share held by indirect controller, the probability of thievish behaviors have been discovered, and the strict punishment regulations. The discussions in this paper help to bring into focus a highly topical issue within the context of the large shareholders' behavior after Non-tradable Shares Reform.

Keywords: related party transactions (RPTs), separation factor, equity restriction, non-tradable shares reform

\section{Introduction}

An increasing number of studies show that publicly listed firms around the world have a concentrated ownership structure (Porta, Lopez-de-Silanes, Shleifer \& Vishny, 1999; Claessens, Djankov \& Lang, 2000). Corporate ownership is concentrated in the hands of the controlling shareholders (Faccio \& Lang, 2002) or the large shareholders. In such a concentrated ownership environment, the agency problem (Shleifer \& Vishny, 1986) arises from the conflicts between the controlling and minority shareholders, particularly when the voting rights of the big shareholders exceed their cash-flow rights (Bozec \& Laurin, 2008). Thus, the existence of investors with high ownership stakes may not lead to firm value maximization. The divergence between the controlling shareholders' voting and cash flow rights motivates the controlling shareholders to expropriate firm resources to pursue their own interest, thereby undermining the firm performance and minority shareholders' interests (Claessens et al., 2000). In this circumstance, there is likely to exist a related party transaction. Although a number of 
definitions exist, RPTs are generically regarded as transactions between a company and related entities such as subsidiaries, affiliates, principal owners, officers, and directors (D'Souza, Ramesh \& Shen 2010). Academic literature has long been interested in the relationship between firm performance and RPTs (La Porta, Lopez-de-Silanes, Shleifer \& Vishny, 2002).

With regard to the means used by the large shareholders to expropriate (tunnel) firm resource, Johnson, La Porta, Lopez-de-Silanes and Shleifer (2000) claimed that the large shareholders could use self-dealing transactions such as asset sales and contracts with advantageous transfer prices as a means of tunneling. Besides, Cheung, Rau and Stouraitis (2006) suggested that certain RPTs such as asset acquisition, asset sales, equity sales, trading relationships and cash payments are a priori likely to result in expropriation of minority shareholders' interest. Jian and Wong (2004) demonstrated that when listed companies have more cash, they will provide generous credits to related parties (RP). These above-mentioned self-dealing or connected party transactions are referred to as RPTs in the field of accounting.

Additionally, the view of potential expropriation, a positive view of RPTs also exists (Jian \& Wong, 2004; Cheung et al., 2006) which considers them as transactions conducted during the proper course of business to enhance the efficiency of an organization by minimizing transaction cost through strong business ties. Listed companies can employ this type of "strategic" RPTs to achieve performance goals by reducing transaction costs (Khanna \& Palepu, 1997). These two opposing perspectives make the issue of whether RPTs benefit firm performance debatable.

Recently, some scholars also pay a lot of attention to the situation of China since the Non-tradable Shares Reform. In April 2005, the China Securities Regulatory Commission (CSRC) promulgated the notice relevant to pilot reform on the segmented shares structure of listed companies as part of its efforts to promote improved corporate governance and stronger capital markets. The notice was intended to reduce the disparity in earnings between tradable and non-tradable shares, ensuring that all of the shareholders in a given company had a common interest. Based on 234 listed companies' data from 2004 to 2006, Hong (2008) make an empirical study on impacting factors on ordinary RPTs before and after the reform of share rights splitting. By using the connected transactions of listed companies from 2004 to 2008 , this paper finds that the largest shareholder will reduce the interest occupy of listed companies and small and medium share-holders after the reform and the effect of reform is initially manifested (Liang \& Yilong, 2011).

In short, the existing literature on large shareholders behavior selection and RPTs studies seldom connected the effect of Non-tradable Shares Reform. The aim of this paper is therefore to explore the large shareholders' behavior from the perspective of RTPs since the Non-tradable Shares Reform. 
The remainder of this paper is organized as follows. Section 2 introduces relative theory and outlines our hypotheses. Section 3 presents the data source and empirical design. Section 4 discusses the empirical results. Section 5 concludes the paper.

\section{Theory and Research Hypotheses}

For a long time, empirical evidence has shown that widely held firms are not the norm in most countries. In a ground breaking study, La Porta, Lopez-de-Silanes, Shleifer and Vishny (1999) show that in many countries outside both the United States and the United Kingdom, companies tend to be owned by controlling shareholders who possess a substantial proportion of voting rights and enjoy almost total control over the firm's operations. For these companies, the agency costs do not result from the traditional conflict between outside shareholders and managers. Instead, the costs are caused by the conflict between large shareholders, who control the firm's assets, and minority shareholders, who provide financing but run the risk of expropriation (Grossman \& Hart, 1988).

In markets with disperse ownership structure, the conflicts of interest between disperse investors and executives are the principal conflicts. Because the costs to monitor executives directly are extremely high for disperse shareholders, they either align the interests of executives with them through incentive contracts or choose "voting by foot" through the market for corporate control. In contrast, the costs to monitor board for large shareholders are low thus they have enough incentives to monitor board directly and alleviate the opportunism problem thereby. So the presence of a controlling shareholder would be beneficial to disperse minority shareholders in the respect of monitoring executives. Minority shareholders played as free riders may entrust large shareholders to monitor executives for them. However, there is no free lunch. Large shareholders' self-interest and opportunism would lead to rent-seeking. They would expropriate disperse investors by their controlling and informational advantages. The stronger for the big shareholders control the firm, the more possibility there exists RPTs. After our capital market entering the era of full circulation, the relationship between the ratio of the controlling shareholder and the related party transaction presents an inverted " $U$ " shape curve, which means that it exits a typical "Grab-synergy" effect (Maury \& Pajuste, 2005; Zengquan, Zheng \& Zhiwei, 2004). When the share ratio of big shareholder is low, he chooses to grab the private controlling benefit to realize his controlling interest. On the contrary, as the increase of share ratio, big shareholders tend to supervise the managers to achieve the sharing controlling benefit.

Based on the Human nature theory, the influence of related party transaction is neutral. To study clearly, we assume that RPTs occurred between the big shareholder and the listed companies are harmful to the interest of our small investors. According to the last empirical test outcome, we can accept or overthrow the assumption at last. This paper therefore establishes the following hypotheses: 
$\mathrm{H} 1$ : When the share ratio of large shareholder is low (say less than $30 \%$ ), the occurrence probability of RPTs increased with the increase of his share ratio; while the share ratio of big shareholder is high (say more than $30 \%$ ), the probability of RPTs decreased.

When there are multiple large shareholders, competition forced the large shareholders to make a commitment to minority shareholders to maximize the firm's profit, which is an effective way of inhibiting RPTs. The deeper equity restriction is, the better the firm's performance is (Maury \& Pajuste, 2005). The second hypothesis is as follow:

$\mathrm{H} 2$ : The deeper the extent of equity restriction existed among the shareholders, the less of the RPTs exist.

Considering the special social background of the state-owned listed companies, the ever "capital constraint" degenerates into "blood transfusion" behavior engaged in RPTs with the listed companies. Therefore, we have come to the third hypothesis:

H3: Compared with non-state-owned enterprises, the largest shareholder of state-owned enterprises tends to choose RPTs to realize its private controlling benefits.

Experience has shown that the better external market environment, the more fierce competition and regulations can largely restrict big shareholders' private interest grabbing behaviors (Cheung et al., 2006). Consequently, we propose the following hypothesis:

H4: The better the external market environment can reduce large shareholders' grabbing benefit more effective.

According to $\mathrm{H} 3$, if state-owned shareholders is more inclined to grab the private benefits by means of RPTs compared with non-state shareholder, the improvement of external market environment have a stronger restriction to state-owned shareholders' grabbing behavior. On the basis of assumption 4, we put forward a sub-hypothesis:

H4a: Compared with non-state shareholder, the improvement of external market environment has a stronger restriction to state-owned shareholders' grabbing behavior

As we discussed in the introduction, two conflicting views are considered when examining RPTs. Some consider RPTs as value creating transactions and a tool of reducing the relative costs, while others consider them a means of expropriating firm's resources. How about the different property nature of the big shareholders? Theoretically, the state-owned shareholders owing to its special background have a motivation to associate with RTPs. Accordingly; we get the following two hypotheses:

H5: State-owned shareholders who associated with RTPs with listed company is likely to expropriate, while non-state-owned shareholders engaged in RPTs probably for reducing transaction costs. 


\section{Data Source and Empirical Design}

\subsection{Data and Sample}

Our study was limited to the post Non-tradable Shares Reform era. According to existing literature, we believe the year 2006 as the first year of Non-tradable Shares Reform era is reasonable. We collected all data from the CSMAR database. The primary sample consists of Ashares data of the Chinese stock exchanges in Shanghai and Shenzhen between 2006 and 2010. Then we excluded share of the financial industry, cross-listed stocks and "ST" stocks. For big shareholders' behavior of "ST" is different from that of the normal listed companies. Finally, we get the sample comprised 242 Chinese listed companies. In addition, the ownership structure data, industry and provincial data are from the Genius database, statistical database of regional GDP data from a research (Gang, Xiaolu \& Henpeng, 2011) of China Economic Information Network, the market environment.

\subsection{Variables and Empirical Models}

\section{Dependent Variables}

RPT is a neutral market behavior. As long as the prices of RPTs are fair and information is disclosed timely, RPTs are legal and accepted. However, the fact of Chinese listed companies is that large shareholders transfer firm's assets in the name of RPTs. Based on the study of Feng, Jiangnag and Minghai (2004), here RPTs mainly focus on the buying and selling assets between large shareholders and listed companies.

\section{Independent Variables}

Independent Variables are divided into three categories that is ownership structure, director characteristics and market environment.

\section{Control variables}

Control variables include assets scale (LnAsset), asset-liability ratio (Debt), the four audit committee (Audit) and year variable (year).

Specific definitions were in Table 1.

To test the "inverted U-shaped" relationship between controlling shareholders and RPTs from the full sample observation, we used the following model (1):

$$
\begin{aligned}
& R P T=\alpha_{0}+\alpha_{1} \text { Top }_{1}+\alpha_{2} \text { Top }_{1}^{2}+\alpha_{3} \text { Top }_{2 \sim 0}+\alpha_{4} \text { Separation }+\alpha_{5} \text { NS }+\alpha_{6} \text { Control }+ \\
& \alpha_{7} \text { Law }+\alpha_{8} \text { LnAsset }+\alpha_{9} \text { Debt }+\alpha_{10} \text { Audit }+\alpha_{11+i} \sum_{i=0}^{2} \text { Year }_{i}+\varepsilon
\end{aligned}
$$




\begin{tabular}{|c|c|c|c|c|}
\hline Category & $\begin{array}{l}\text { Kind of } \\
\text { Variables }\end{array}$ & Name of Variables & Code & Definition and Description \\
\hline & & $\begin{array}{l}\text { Related Party } \\
\text { Transactions }\end{array}$ & RPTs & $\begin{array}{l}\text { Selling of RP/ operating income+sourcing of } \\
\text { RP/operating cost }\end{array}$ \\
\hline & Variables & Firm performance & Tobin'Q & $\begin{array}{l}\text { The sum of market value of equity and the } \\
\text { book value of debt divided by the book value } \\
\text { of the total assets. }\end{array}$ \\
\hline \multirow{4}{*}{$\begin{array}{l}\text { Ownership } \\
\text { Structure }\end{array}$} & \multirow{7}{*}{$\begin{array}{l}\text { Independent } \\
\text { Variables }\end{array}$} & $\begin{array}{l}\text { Ratio of the largest } \\
\text { shareholder }\end{array}$ & Top1 & The largest shareholder' shares/ total shares \\
\hline & & Separation factor & Separation & $\begin{array}{l}\text { Based on Claessens et al. ( } 2000 \text { ) study, } \\
\text { Separation = cash-flow rights/ voting rights }\end{array}$ \\
\hline & & Equity restriction & Top2-10 & $\begin{array}{l}\text { Sum of the second to the tenth } \\
\text { shareholders' shareholding ratio }\end{array}$ \\
\hline & & $\begin{array}{l}\text { Large state-owned } \\
\text { shareholder }\end{array}$ & NS & $\begin{array}{l}\text { Dummy variable, the controlling } \\
\text { shareholders are government agencies, } \\
\text { state-owned firms or schools, NS }=1 \text {, } \\
\text { otherwise, the NS = } 0\end{array}$ \\
\hline \multirow[b]{2}{*}{$\begin{array}{l}\text { Board } \\
\text { Characteristics }\end{array}$} & & Board scale & Board & Number of board members \\
\hline & & $\begin{array}{l}\text { Ratio of directors } \\
\text { appointed by controlling } \\
\text { shareholders }\end{array}$ & Control & $\begin{array}{l}\text { Directors appointed by large } \\
\text { shareholders/total directors }\end{array}$ \\
\hline $\begin{array}{l}\text { Market } \\
\text { Environment }\end{array}$ & & Environment of Law & Law & Legalization index \\
\hline \multirow{4}{*}{ Firm Level } & \multirow{4}{*}{$\begin{array}{l}\text { Control } \\
\text { Variables }\end{array}$} & Asset scale & LnAsset & Logarithm of total assets \\
\hline & & Asset-liability ratio & Debt & Total debt/total assets. \\
\hline & & $\begin{array}{l}\text { The four audit } \\
\text { committee }\end{array}$ & Audit & $\begin{array}{l}\text { Dummy variable if the firm is one of the } \\
\text { biggest four and it committee, the } \\
\text { Audit }=1 \text {, otherwise, the Audit }=0\end{array}$ \\
\hline & & Year & Year & $\begin{array}{l}\text { Dummy variable, set to } 1 \text { if data of the } \\
\text { sample is the year 2007, } 0 \text { Otherwise, and } \\
\text { so on. }\end{array}$ \\
\hline
\end{tabular}

Table 1. Variables Defined and Descriptive Statistics

\section{Equation (2) is used to verify Hypothesis $\mathrm{H} 4 \mathrm{a}$}

$$
\begin{aligned}
& R P T=\alpha_{0}+\alpha_{1} \text { Top }_{1}+\alpha_{2} \text { Top }_{2 \sim 10}+\alpha_{3} \text { Separation }+\alpha_{4} \text { Control }+\alpha_{5} N S+\alpha_{6} N S \times \text { Law } \\
& +\alpha_{7} \text { LnAsset }+\alpha_{8} \text { Debt }+\alpha_{9} \text { Audit }+\alpha_{10+i} \sum_{i=0}^{2} \text { Year }_{i}+\varepsilon
\end{aligned}
$$

In order to analyze the true intention of the large shareholders' RPTs with the listed companies form the respective of property rights and firm performance, we have established the following model:

$$
\text { Tobin } Q=\alpha_{0}+\alpha_{1} R P T+\alpha_{2} T_{0} p_{1}+\alpha_{3} \text { Separation }+\alpha_{4+i} \sum_{i=0}^{2} \text { Year }_{i}+\varepsilon
$$




\subsection{Descriptive Statistics}

From the above table 2, ownership structure is quite concentrated with the average proportion $32.94 \%$. Separation between cash-flow rights and voting rights is 0.80 on average. Besides, $77 \%$ controlling shareholders are state-owned. As for board scale, a typical Chinese listed company has more than nine people and $27.9 \%$ of directors among them are appointed by the controlling shareholder on average. In addition, 36.2 \% are independent, which slightly meet the China Securities Regulatory Commission requirement. Only about 5\% of listed companies to accept the big four audit committee services.

\begin{tabular}{|l|c|c|c|c|}
\hline \multicolumn{1}{|c|}{ Variables } & Min. & Max. & Mean & St. Dev. \\
\hline RPT & 6.22 & 28.72 & 19.6529 & 2.11332 \\
\hline TOP1 & 0.00 & 0.84 & 0.3294 & 0.16763 \\
\hline TOP2-10 & 0.0096 & 0.5204 & 0.140488 & 0.104874 \\
\hline SEPERATION & .08 & 1.00 & 0.8039 & 0.25046 \\
\hline NS & 0 & 1 & 0.77 & 0.420 \\
\hline BOARD & 5 & 17 & 9.52 & 1.930 \\
\hline CONTROL & 0.000 & 0.750 & 0.279 & 0.166 \\
\hline INDEP & 0.1250 & 0.5714 & 0.3620 & 0.0515 \\
\hline LAW & 2.11 & 16.61 & 6.8578 & 3.2187 \\
\hline LNASSENT & 19.2362 & 25.8100 & 22.0363 & 1.0318 \\
\hline DEBT & 0.0108 & .8857 & 0.5234 & 0.1658 \\
\hline AUDIT & 0 & 1 & 0.05 & 0.213 \\
\hline
\end{tabular}

Notes: This table reports summary statistics, period between 2006 and 2010, 242 firm-year observations, obtained from CSMAR database. See, the Appendix for definitions of variables.

Table 2. Descriptive Statistics

\section{Empirical Findings}

In order to avoid multicollinearity problems, we adopt Pearson method to test the correlation coefficient between the independent variables. The correlation analysis results were shown in table 3.

\begin{tabular}{|l|c|c|c|c|c|c|c|c|c|}
\hline & TOP1 & TOP2-10 & SEPR. & NS & CONTROL & LLAW & NASSENT & DEBT & AUDIT \\
\hline RPT & $189(* * *)$ & -.041 & 007 & $.131(* * *)$ & $131(* * *)$ & -.031 & $.502(* * *)$ & $.171(* * *)$ & $.109(* * *)$ \\
\hline TOP1 & 1 & $-.389(* * *)$ & $.104(* * *)$ & $.206(* * *)$ & $.248(* * *)$ & $-.103(* * *)$ & $.262(* * *)$ & -.029 & .049 \\
\hline TOP2-10 & & 1 & $-.078(* *)$ & $-.221(* * *)$ & $-.135(* * *)$ & $-.081(* *)$ & -.042 & $-.136(* * *)$ & $.160(* * *)$ \\
\hline SEPE. & & & 1 & $.477(* * *)$ & .034 & -.029 & $.125(* * *)$ & .010 & .025 \\
\hline NS & & & & 1 & $.112(* * *)$ & $-.185(* * *)$ & $.123(* * *)$ & $.148(* * *)$ & .052 \\
\hline CONTROL & & & & & 1 & $.065(* *)$ & $.228(* * *)$ & .052 & .056 \\
\hline LAW & & & & & & 1 & -.034 & -.057 & $.076(* *)$ \\
\hline LNASSENT & & & & & & & 1 & $.307(* * *)$ & $.257(* * *)$ \\
\hline DEBT & & & & & & & & & 1 \\
\hline AUDIT & & & & & & & & -.018 \\
\hline
\end{tabular}

Note: $* * *, * *$, indicate significance at the level of $1 \%$ and $5 \%$ respectively.

Table 3. Variables Pearson Analysis 
From table 3, share ratio of the largest shareholder, ratio of directors appointed by controlling shareholders, state-owned shareholder, asset scale, and asset-liability ratio is positively associated with the possibility of the RPTs. This means that the higher the relatively indicator, the more possibility engaged with RPTs undertaken by Chinese listed companies. In addition, there is a negative relationship between equity restrictions, environment of law is negatively associated with the RPTs. Although the improvement of law environment and structure balance has an effect on restricting the RPTs, the outcome is limited.

\section{Regression Analysis}

\begin{tabular}{|c|c|c|c|c|c|c|}
\hline \multirow[b]{2}{*}{ Code } & \multicolumn{3}{|c|}{ Model (1) } & \multicolumn{3}{|c|}{ Model (2) } \\
\hline & $\begin{array}{c}\text { (i) Subsample } 1 \\
(<30 \%)\end{array}$ & $\begin{array}{c}\text { (ii) Subsample } 2 \\
(\geq 30 \%)\end{array}$ & (iii) Sample & $\begin{array}{l}\text { (iv) Subsample } \\
(<30 \%)\end{array}$ & $\begin{array}{l}\text { (v) Subsample } \\
(\geq 30 \%)\end{array}$ & $\begin{array}{c}\text { (vi) } \\
\text { Sample }\end{array}$ \\
\hline \multirow{2}{*}{ C } & -1.666 & 2.029 & -1.560 & -1.281 & 1.596 & -1.688 \\
\hline & .564 & .230 & .283 & .652 & .339 & .237 \\
\hline \multirow{2}{*}{ TOP1 } & 1.796 & -.747 & 1.346 & 1.816 & -.702 & 1.316 \\
\hline & $.048 * *$ & .132 & .065 & .048 & .363 & .074 \\
\hline \multirow{2}{*}{$T o p_{1}^{2}$} & & & -.624 & & & -.582 \\
\hline & & & .094 & & & .552 \\
\hline \multirow{2}{*}{ TOP2-10 } & 1.221 & -.289 & .754 & 1.162 & -.189 & .758 \\
\hline & .188 & .238 & .239 & .212 & .826 & .237 \\
\hline \multirow{2}{*}{ SEPE. } & -.739 & -3.060 & -.767 & -.702 & -3.103 & -.785 \\
\hline & .086 & $.000 * * *$ & .034 & .100 & .000 & .029 \\
\hline \multirow{2}{*}{ NS } & .787 & .302 & .564 & .620 & .544 & .679 \\
\hline & .001 & .024 & .001 & .055 & .065 & .001 \\
\hline \multirow{2}{*}{ CONTROL } & -.635 & .803 & .093 & -.578 & .794 & .083 \\
\hline & .281 & .071 & .797 & .322 & .075 & .817 \\
\hline \multirow{2}{*}{ LAW } & .025 & -.043 & -.014 & & & \\
\hline & .394 & .095 & .082 & & & \\
\hline \multirow{2}{*}{ LAW*NS } & & & & .018 & -.026 & -.014 \\
\hline & & & & .605 & .343 & .524 \\
\hline \multirow{2}{*}{ LNASSENT } & .959 & .949 & .968 & .949 & .952 & .970 \\
\hline & $.000 * * *$ & .000 & .000 & .000 & .000 & .000 \\
\hline \multirow{2}{*}{ DEBT } & .154 & .253 & .152 & .159 & .266 & .148 \\
\hline & .787 & .609 & .685 & .781 & .591 & .694 \\
\hline \multirow{2}{*}{ AUDIT } & -.661 & -.103 & -.231 & -.650 & -.140 & -.231 \\
\hline & .227 & .348 & .416 & .235 & .665 & .417 \\
\hline YEAR & controlled & Controlled & controlled & controlled & controlled & controlled \\
\hline Adj. $R^{2}$ & .227 & .401 & .311 & .205 & .398 & .311 \\
\hline F Value & 10.595 & 29.854 & 34.435 & 10.545 & 29.586 & 34.425 \\
\hline
\end{tabular}

Note: Data in the first line are coefficient; Data in the second line are $\mathrm{P}$ value. $* * *, * *$, indicate significance at the level of $1 \%$ and $5 \%$ respectively. Subsample $1(<30 \%)$ means the proportion of the largest shareholder is less than $30 \%$, similarly, subsample 2 ( $\geq 30 \%$ ) is more than $30 \%$.

Table 4. Regression Result of Model (1), (2) 
According to result (i), coefficient of Top1 is positively significant at the level of $5 \%$. This means when the share proportion of the largest shareholder is less than $30 \%$, RPTs undertaken between controlling shareholder and listed companies increased as the increase of the share ratio of big shareholders. On the contrary, when that is over $30 \%$, RPTs lessened seeing result (ii). Checking the whole sample (iii), the coefficient of $T o p_{1}{ }^{2}$ is -0.624 . Just as we expected, the relationship between the ratio of the control shareholder and RPTs presents an inverted " $U$ " shape curve. In another word, there indeed exit a typical "Grab-synergy" effect. Consequently, $\mathrm{H} 1$ are supported. Analyses similarly, we find both $\mathrm{H} 3$ and $\mathrm{H} 4$ are supported according to table 4 .

\section{Property Rights and Large Shareholders Behavior Selection}

RTPs should not be any that a bad thing. It is neutral by nature. After the Non-tradable Shares Reform, whether different property rights of controlling shareholders associated with RPTs will lead to different effect on the firm performance? Next we will discuss the answer to this question.

\begin{tabular}{|l|c|c|c|c|}
\hline \multicolumn{1}{|c|}{ Variables } & \multicolumn{2}{c|}{ State-owned shares } & Non-State-owned shares \\
\hline C & 3.626 & .000 & .456 & .601 \\
\hline RPT & -.098 & .000 & .096 & .021 \\
\hline TOP1 & 2.087 & .000 & .815 & .259 \\
\hline SEPR. & -.026 & .915 & .157 & .648 \\
\hline YEAR & Controlled & controlled & controlled & controlled \\
\hline Adj. $R^{2}$ & \multicolumn{3}{|c|}{.218} & \multicolumn{2}{c|}{.191} \\
\hline F Value & \multicolumn{2}{|c|}{35.504} & \multicolumn{2}{c|}{9.640} \\
\hline
\end{tabular}

Table 5. Regression Result of Model (3)

When the ultimate controlling shareholders are state-owned, there is a negative relationship between RPTs and the performance of listed companies, significant at the $1 \%$ level. However, when Non-state-owned, that is a significant positive relationship. Separation factor is not significantly associated with the firm performance both in two subsamples. A plausible explanation for this is that entering the era of full share circulation, either state-owned or Nonstate-owned, the separation of voting rights from cash-flow rights has improved a lot.

\section{Conclusion}

Based on the RPTs data between 2007 and 2010, we analyze the large shareholder's expropriating behavior. The following conclusions were drawn.

First of all, when the share proportion of the largest shareholder is low (say less than $30 \%$ ), RPTs undertaken between controlling shareholder and listed companies increased as the increase of the share ratio of big shareholders. Firms are exposed to an entrenchment problem, which is a situation where the dominant shareholders have the power to use the firm 
in the pursuit of their own interests rather than the interests of all shareholders. While big shareholder tends to supervise the managers to achieve the sharing controlling benefit when that ratio is big enough.

Secondly, compared to non-state-owned shareholders, state-owned shareholders are more apt to achieve their private benefits by means of RPTs. This is an institutional background of lessening state-owned shares holding. Sound external market environments especially the law environment help to curb the controlling shareholder's grab behavior. Therefore, the improvement of law environment is more helpful to restrict state-owned shareholders' RPTs compared with that of non -state-owned shareholders.

Thirdly, larger companies are more inclined to associate with RPTs with listed firms. The bigger the separation between voting and cash-flow rights, the smaller the controlling shareholders' expropriation cost. For this reason, the independent director system is introduced to our capital market. However, its effect is too far from our expectation.

Finally, empirical studies have found that different property nature have different reaction. Because state-owned companies have more social burden, they will expropriate minority shareholders' interests through RPTs. The state-own companies associated with RPTs mostly want to pursue their private interests. In contrast, non -state owned businesses are engaged in RPTs expecting to save transaction cost.

\section{References}

Bozec, Y., \& Laurin, C. (2008). Large shareholder entrenchment and performance: Empirical evidence from Canada. Journal of Business Finance \& Accounting, 35, 25-49. http://dx.doi.org/10.1111/j.1468-5957.2007.02066.x

Cheung, Y., Rau, P.R., \&. Stouraitis, A. (2006). Tunneling, Propping, and Expropriation: Evidence from Connected Party Transactions in Hong Kong, Journal of Financial Economics, 82, 343-386. http://dx.doi.org/10.1016/j.jfineco.2004.08.012

Claessens, S., Djankov, S., \& Lang, L.H.P. (2000). The Separation of Ownership and Control in East Asian Corporations. Journal of Financial Economics, 58,81-112. http://dx.doi.org/10.1016/S0304-405X(00)00067-2

Dang, H. (2008). Empirical study on impacting factors on ordinary related party transactions before and after the reform of share rights splitting. Journal of Modern Accounting and Auditing, 4(10), 9-17.

D'Souza, J.M., Ramesh, K., \& Shen, M. (2010). The Interdependence between Institutional Ownership and Information Dissemi nation by Data Aggregators,. The Accounting Review. http://dx.doi.org/10.2308/accr.2010.85.1.159

Faccio, M., \& Lang, L.H.P. (2002). The Ultimate Ownership of Western European Companies. Journal of Financial Economics, 65, 365-395. http://dx.doi.org/10.1016/S0304-405X(02)00146-0 
Feng, L., Jiangnag, H., \& Minghai, W. (2004). Controlling Rights., Firm Performance and Interest Transfer - Analysis based on a Case of Wuliangye. Management World, 8, 102-110.

Gang, F., Xiaolu, W., \& Henpeng, Z. (2011). Index of Chinese Market. Beijing: Economic Science Press.

Grossman, S., \& Hart, O. (1988). Take over bids the free rider problem, and the theory of the corporation. Journal of Economics, 11, 42-64.

Jian, M., \& Wong, T.J. (2004). Earnings management and tunneling though related party transactions: evidence from Chinese corporate groups. Working Paper. Hong Kong: The Hong Kong University of Science and Technology.

Johnson, S., La Porta, R., Lopez-de-Silanes, F., \& Shleifer, A. (2000). Tunneling. The American Economic Review, 90, 22-27. http://dx.doi.org/10.1257/aer.90.2.22

Khanna, T., \& Palepu, K. (1997). Why focused strategies may be wrong for emerging markets. Harvard Business Review, 75(4), 41-51.

La Porta, R., Lopez-de-Silanes, F., Shleifer, A., \& Vishny, R. (1999). Corporate ownership around the world. Journal of Finance, 54, 471-517. http://dx.doi.org/10.1111/0022-1082.00115

La Porta R., Lopez-de-Silanes, F., Shleifer, A., \& Vishny, R. (2002). Investor Protection and Corporate Valuation. Journal of Finance, 57, 1147-1170. http://dx.doi.org/10.1111/15406261.00457

Liang, W., \& Yilong, Y. (2011). Will Large Shareholders Reduce "Tunneling" Behavior after the Split Structure Reform? Finance and Trade Research, 1, 110-118.

Maury, B., \& Pajuste, A. (2005). Multiple Large Shareholders and Firm Value. Journal of Banking and Finance, 7, 1813-1834. http://dx.doi.org/10.1016/j.jbankfin.2004.07.002

Shleifer, A., \& Vishny, R. (1986). Large Shareholders and corporate Control. Journal of Political Economy, 11, 5-50.

Zengquan, L., Zheng, S., \& Zhiwei, W. (2004). Tunneling and Ownership Structure of a Firm: Evidence from Controlling Shareholder s Embezzlement of Listed Company's Funds in China. Accounting Research, 12, 3-13.

Journal of Industrial Engineering and Management, 2013 (www.jiem.org)

Article's contents are provided on a Attribution-Non Commercial 3.0 Creative commons license. Readers are allowed to copy, distribute and communicate article's contents, provided the author's and Journal of Industrial Engineering and Management's names are included. It must not be used for commercial purposes. To see the complete license contents, please visit http://creativecommons.org/licenses/by-nc/3.0/. 